\title{
Characteristics of Human Surfactant-Associated Glyoproteins A
}

\author{
JEFFREY A. WHITSETT, WILLIAM HULL, GARY ROSS, AND TIMOTHY WEAVER
}

University of Cincinnati Medical Center, Department of Pediatrics, Newborn Division, Cincinnati, Ohio 45267

\begin{abstract}
Surfactant-associated glycoprotein A [molecular weight $(\mathrm{Mr})=34,000$, isoelectric point $(\mathrm{pI}) 4.6-5.0$ ] and its sulfhydryl dependent oligomers were purified and partially characterized from surfactant obtained from human alveolar lavage. Two major forms of the protein were identified by silver stain and immunoblot analysis of surfactant using human surfactant-associated glycoprotein $\mathbf{A}$ antisera: glycoprotein $A_{2}, M r=34,000$ and glycoprotein $\mathrm{A}_{1}, \mathrm{Mr}=28,000$. The larger form was reduced to $\mathrm{Mr}=$ 28,000 by treatment with endogylcosidase $F$, indicating the presence of complex $\mathrm{N}$-linked oligosaccharide on the molecule. Charge heterogeneity was decreased and the isoelectric point increased by treatment with neuroaminidase, supporting the presence of sialic acid. Homology between the proteins $\mathrm{Mr}=34,000$ and 28,000 was confirmed by analysis of two-dimensional tryptic and chymotryptic peptides of ${ }^{125}$ I-iodo-glycoproteins $A_{1}$ and $A_{2}$ which were identical. The protein was very rich in glycine and its amino acid composition was similar to that of glycoprotein $A$ previously reported for the $\operatorname{dog}$ and rat. Treatment of glycoproteins A with bacterial collagenase resulted in the generation of highly glycosylated peptides $\mathrm{Mir}=\mathbf{2 0 , 0 0 0 -}$ 22,000 , pI 4.6-5.0, which no longer formed sulfhydryldependent oligomers, supporting the presence of significant collagen-like region in the molecule. In the absence of reducing agents, glycoprotein A from surfactant was present as sulfhydryl-dependent dimers and larger oligomers. Higher molecular weight aggregates of glycoproteins A were also present in lavage material even after sulfhydryl reduction. Glycoproteins A were identified in surfactant from amniotic fluid, normal adult lung lavage, human cadaver lung lavage, and material obtained from lung lavage from a patient with alveolar proteinosis. Alveolar proteinosis proteins contained larger amounts of the higher molecular weight aggregates and smaller molecular weight proteolytic fragments of glycoproteins A than material obtained from other sources. Peptide mapping of the ${ }^{125} I-$ iodinated aggregates, approximately $\mathrm{Mr}=50,000,70,000$, 100,000 , and greater were identical to glycoproteins $\mathrm{A}(\mathrm{Mr}$ $=34,000$ and 28,000) from normal human lung lavage. $A$ smaller immunoreactive form $(\mathrm{Mr}=20,000)$ shared several peptides but lacked others, supporting its origin as a proteolytic fragment of glycoproteins $A_{1}$ or $A_{2}$. Human glycoprotein $\mathbf{A}_{2}$ is a complex $\mathrm{N}$-linked glycoprotein likely representing the glycosylated form of a polypeptide precursor $\mathrm{Mr}=28,000$. (Pediatr Res 19: 501-508, 1985)
\end{abstract}

Received October 1, 1984; accepted January 11, 1985

J A.W supported by Research Career Development Award HL01024 from National Institutes of Health and HL28623, HD11725 and HD17000, Cincinnati, OH; T.W. supported by Research Training in Perinatology HD 07200; G.R. supported by a Postdoctoral Award from Children's Hospital Research Foundation.

\author{
Abbreviations \\ pI, isoelectric point \\ $\mathrm{Mr}$, molecular weight \\ PMSF, phenylmethylsulfonylfluoride \\ SDS-PAGE, sodium dodecyl sulfate polyacrylamide gel \\ electrophoresis \\ 2-D-IEF-PAGE, two-dimensional IEF PAGE \\ IEF-SDS-PAGE, isoelectric focusing SDS PAGE
}

Pulmonary surfactant-associated proteins have been identified in lung lavage material from a variety of species including the human (1). Although there is controversy regarding the physiologic role of the surfactant-associated proteins, the protein components of pulmonary surfactant appear to alter its physicochemical properties (2-5). Canine glycoprotein A binds to phospholipids and enhances the spreading of lipid monolayers and adsorption to the air liquid interface (2). Addition of surfactant-associated proteins to phospholipids produces a preparation with properties similar to natural lung surfactant. Recent surfactant preparations for treatment of respiratory distress syndrome in premature infants have included lung proteins prepared from bovine lung or from human amniotic fluid, respectively (6-9).

Although a number of surfactant-associated proteins have been reported, the major forms apparently somewhat similar in all species are glycoproteins $\mathrm{A} \mathrm{Mr}=30,000-40,000$ first described by King and Clements (10). These proteins migrate as complex acidic proteins, pl $4.2-5.0, \mathrm{Mr}=30,000-40,000$ with a minor component migrating at approximately $\mathrm{Mr}=26,000$ in the rat and dog (11-13). Similar glycoprotein has been identified in lung lavage fluid obtained from patients with alveolar proteinosis (14). Bhattacharyya and Lynn (14) previously characterized surfactant-associated glycoproteins and provided data that the molecules migrating with $\mathrm{Mr}=30,000-40,000$ are fragments of a larger $\mathrm{Mr}=80,000$ dalton polypeptide and have recently described complex N-linked carbohydrates on these molecules (15). Several distinct proteins reactive with antisera generated against glycoprotein A have been identified with characteristics of glycoproteins $A$ in lung lavage fluid (16). Identity and relationships among the various molecular weight forms described of the surfactant-associated proteins remain somewhat unclear. Shelly et al. (17) have characterized glycoprotein from human cadaver lung lavage, demonstrating similar proteins with molecular weight approximately 400,000 which upon sulfhydryl reduction produced peptides of 34,000 daltons. In that study, antisera prepared against this human protein selectively stained human alveolar type II cells and the alveolar lining of human lung. Despite progress with the characterization of surfactant-associated proteins, the identity and relationships among the surfac- 

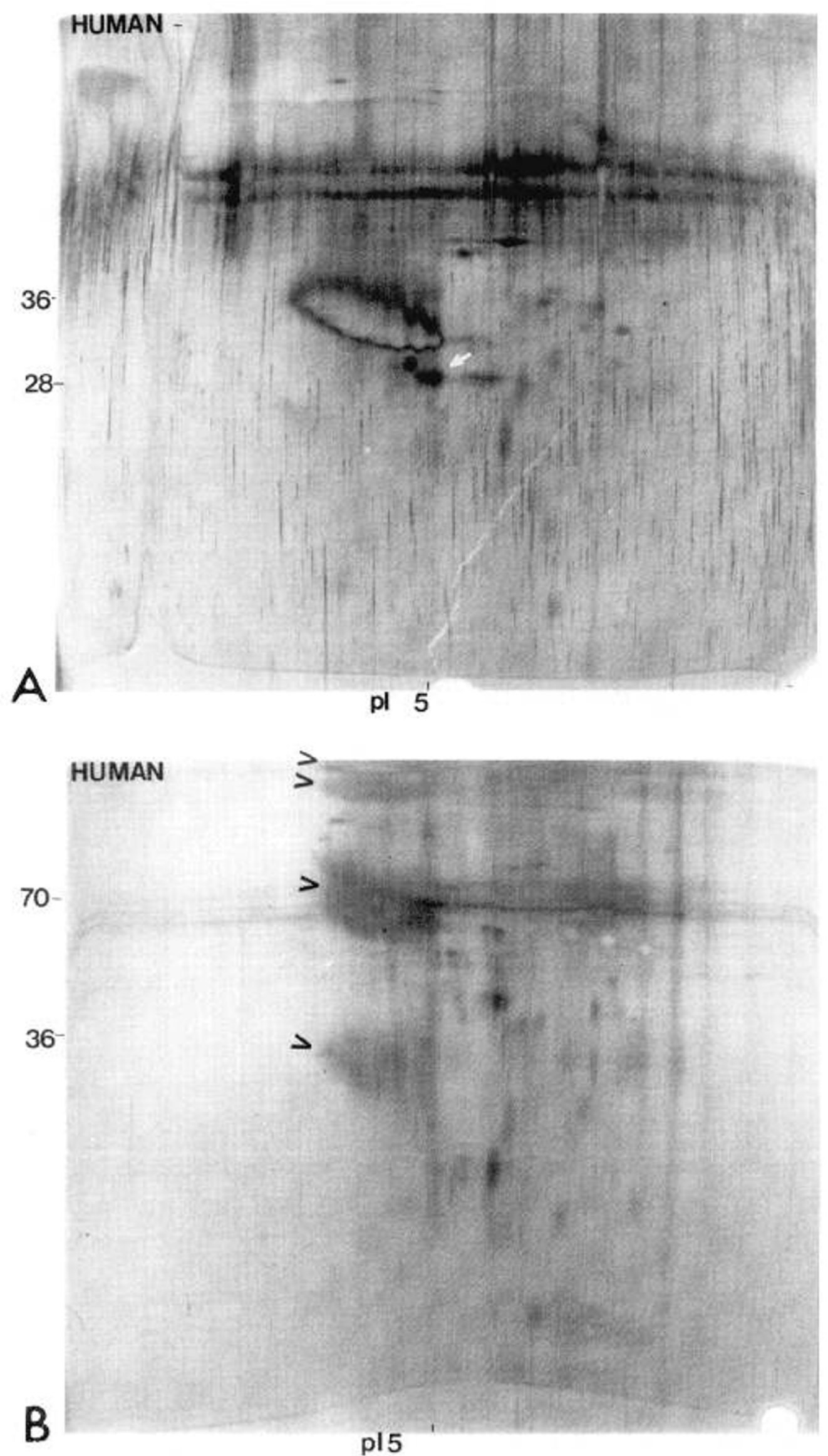

Fig. 1. A, silver stain analysis of 2-D-IEF-polyacrylamide gel electrophoresis of surfactant-assoicated glycoproteins. Surfactant obtained from lung lavage material, approximately $15 \mu \mathrm{g}$ protein, was separated by isoelectric focusing in the horizontal plane (pH range 4-6) followed by electrophoresis in $10 \%$ polyacrylamide in the vertical plane in the presence of $1 \mathrm{mM} \beta$-mercaptoethanol. Glycoproteins A were stained characteristically salmon pink and the major form migrated with $\mathrm{Mr}$ approximately equal $36,000, \mathrm{pI} 4.6-5$. Molecular weights are noted to the left $\times 10^{-3} . B$, represents identical experiment in the absence of sulfhydryl reduction. 
tant-associated proteins from normal human surfactant and the larger molecular weight forms found in human alveolar proteinosis material remain unclear.

\section{METHODS}

Samples of human surfactant were obtained under protocols approved by the Humn Research Committee of the University of Cincinnati College of Medicine and Children's Hospital, Cincinnati, $\mathrm{OH}$. Selected bronchial lavage from adult volunteers was used to obtain adult human surfactant under an approved protocol. Surfactant from lung lavage was collected in $0.9 \%$ sodium chloride and placed in ice. The sample was filtered through two layers of cheese cloth and pelleted at $1000 \times g$ for $5 \mathrm{~min}$ at $4^{\circ} \mathrm{C}$. Supernatant was removed and the centrifugation step repeated. Supernatant was then centrifuged $40,000 \times g$ for $20 \mathrm{~min}$ and the dense pellet collected in $0.9 \%$ sodium chloride, $1 \mathrm{mM}$ PMSF (phenylmethylsulfonylfluoride) and stored at $-80^{\circ} \mathrm{C}$. Amniotic fluid samples were obtained at elective cesarian section at term. Surfactant was prepared from amniotic fluid as described above. Lung lavage samples were also obtained at autopsy by lung lavage with $0.9 \%$ sodium chloride, surfactant prepared as described above.

Antisera against amniotic fluid surfactant was prepared in New Zealand rabbits by injection of partially purified lavage material in Freund's adjuvant. Antisera were extensively adsorbed with human red blood cells and human serum-Sepharose affinity column and produced an antisera selectively reactive for glycoprotein A. Monospecific antisera were generated using human glycoprotein $\mathrm{A}_{2}(\mathrm{Mr}=34,000)$ electroeluted from 2-D-IEFPAGE as described by Hunkapiller et al. (18) as the immunogen. Silver-stain analysis of this immunogen was entirely homogene- ous for glycoprotein $\mathrm{A}_{2}$. This antisera cross-reacts with glycoprotein $\mathrm{A}$ from the dog and the rat as assessed by immunoblots of the surfactant after IEF-SDS-PAGE.

Analysis of protein was carried out by immunoblot, silver, and Coomassie staining. Purified lavage surfactant was pelleted, resuspended in buffer containing $2 \%$ SDS and $\beta$-mercapthoethanol as described by Laemmli (19), for one-dimensional SDS-PAGE or in the buffer used by Anderson and Anderson (20), for 2-DIEF-PAGE as described by Garrison and Johnson (21). Isoelectric points were determined from the focusing gels by excision of 1 $\mathrm{cm}$ pieces which were placed in $2 \mathrm{ml}$ distilled degassed water for determination of $\mathrm{pH}$. Unfixed gels were used for immunoblot analysis and proteins transferred electrophoretically to nitrocellulose and treated with antiglycoprotein 1:100 or 1:300 dilution of antisera followed by horseradish peroxidase-conjugated goat antirabbit IgG. Color was developed as described by Towbin et al. (22) except that 4-chloro-napthol was used as a substrate. Gelatin (3\%) was included in the incubation to reduce nonspecific background color (23). Molecular weight markers included unlabeled and ${ }^{14} \mathrm{C}$-labeled myosin $(220,000)$ phosphorylase B $(93,000)$, bovine serum albumin $(69,000)$, ovalbumin $(46,000)$, carbonic anhydrase $(30,000)$, and lysozyme $(14,000)$ obtained from Amersham, Arlington Heights, IL. Silver staining was performed by a slight modification of the procedure of Sammons et al. (24) in which $5 \%$ acetic acid was used to control background staining following a 5-10 min $\mathrm{Na}_{2} \mathrm{CO}_{3}$ color development step. Figures are generally representative of at least three separate experiments.

Peptide mapping of glycoprotein(s) A. Glycoproteins $\mathrm{A}_{1}$ and $\mathrm{A}_{2}$ were lightly stained with Coomassie brilliant blue and excised from the 2-D-IEF-SDS-PAGE gels of reduced alveolar lavage surfactant. Stain was removed by shaking the gels in methanol

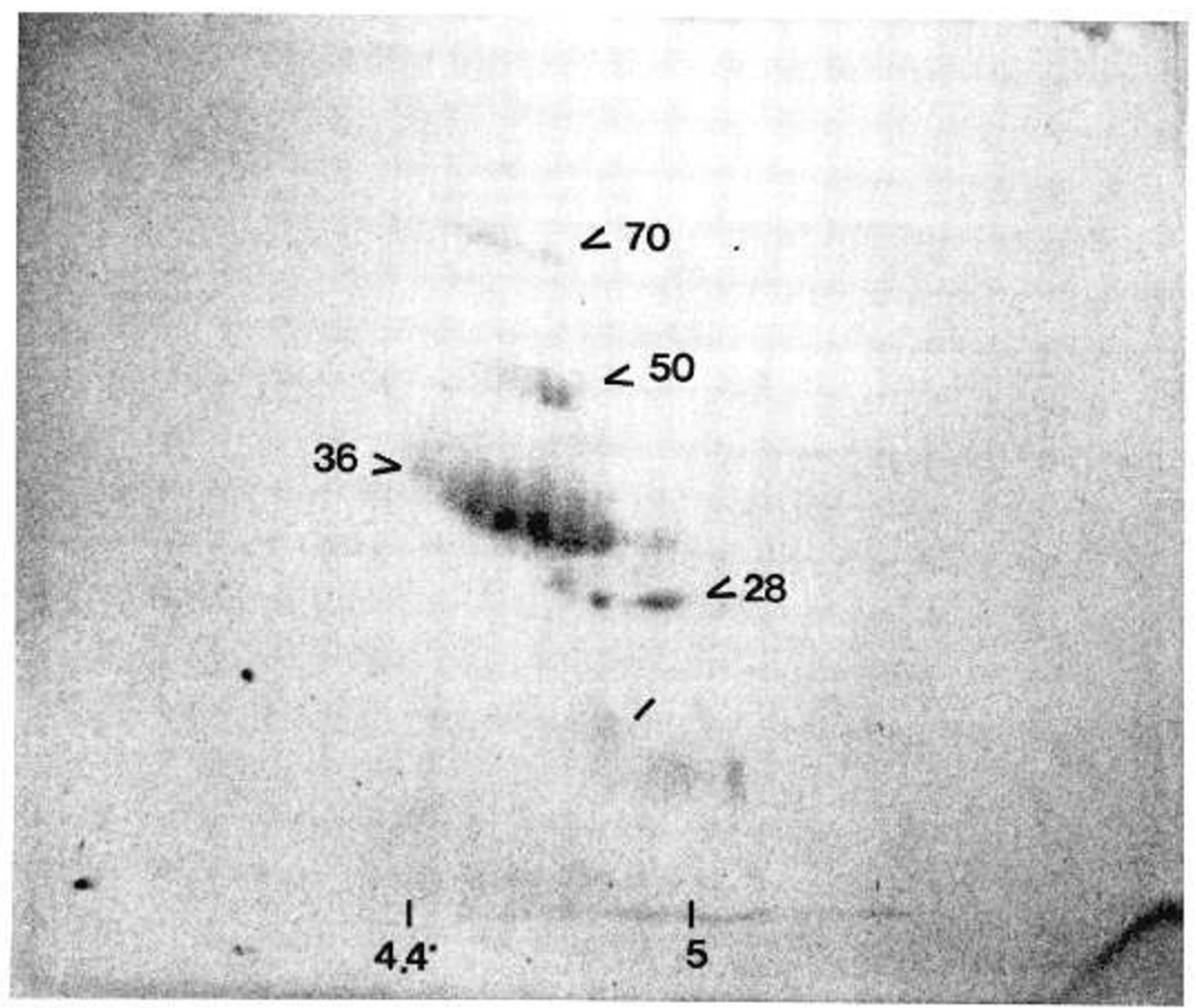

Fig. 2. Immunoblot analysis of surfactant-associated proteins separated by 2-D-IEF-polyacrylamide gel electrophoresis in the presence of $\beta$ mercaptoethanol. Surfactant obtained from human alveolar lavage was subjected to electrophoresis and immunoblotted as described in "Methods." Immunoreactivity was assessed with the antihuman glycoprotein $\mathrm{A}$ antisera. Molecular weights are $\times 10^{-3}$. 
prior to peptide mapping as described by Elder and Alexander (25). Proteins were iodinated with ${ }^{125} \mathrm{I}$-iodine $(17.4 \mathrm{mCi} / \mathrm{mg})$ by the chloromine $\mathrm{T}$ method dialyzed against $10 \%$ methanol, lyopholized and incubated with chymotrypsin $(50 \mu \mathrm{g} / \mathrm{ml})$, and trypsin $(50 \mu \mathrm{g} / \mathrm{ml})$ in $50 \mathrm{mM}$ ammonium acetate, $\mathrm{pH} 8.0$ for 16 $\mathrm{h}$ at room temperature $(26) .{ }^{125}$ I-iodopeptides were isolated by electrophoresis and thin-layer chromotography as described by Gibson (27), and subjected to autoradiography. Peptide maps of normal lung lavage and alveolar proteinosis samples were obtained in a similar manner.

Treatment of surfactant glycoproteins with endoglycosidase $F$, collagenase, and neuraminidase. Endo- $\beta$-N-acetylglucosaminidase $\mathrm{F}$ (endoglycosidase F) from Flavobacterium menisigosepticum was purchased from New England Nuclear, Boston, MA. Neuroaminidase was purchased from Calbiochemical, LaJolla, CA. Lung lavage material was delipidated by the chloroformmethanol extraction as described by Folch and Less (28). Extracted lavage proteins were solubilized in $0.5 \mathrm{ml}$ of $0.1 \mathrm{M}$ of Tris- $\mathrm{Cl} \mathrm{pH} 8.2$ containing $1 \%$ SDS, $1 \% \beta$-mercapthoethanol, and boiled for $2 \mathrm{~min}$. Reduced sulfhydryl bonds were alkylated by addition of $0.15 \mathrm{ml}$ of $1 \mathrm{M}$ iodoacetamide in $0.1 \mathrm{M}$ Tris- $\mathrm{Cl}$, $\mathrm{pH}$ 8.2. Following incubation at room temperature for $30 \mathrm{~min}$,

\section{A}

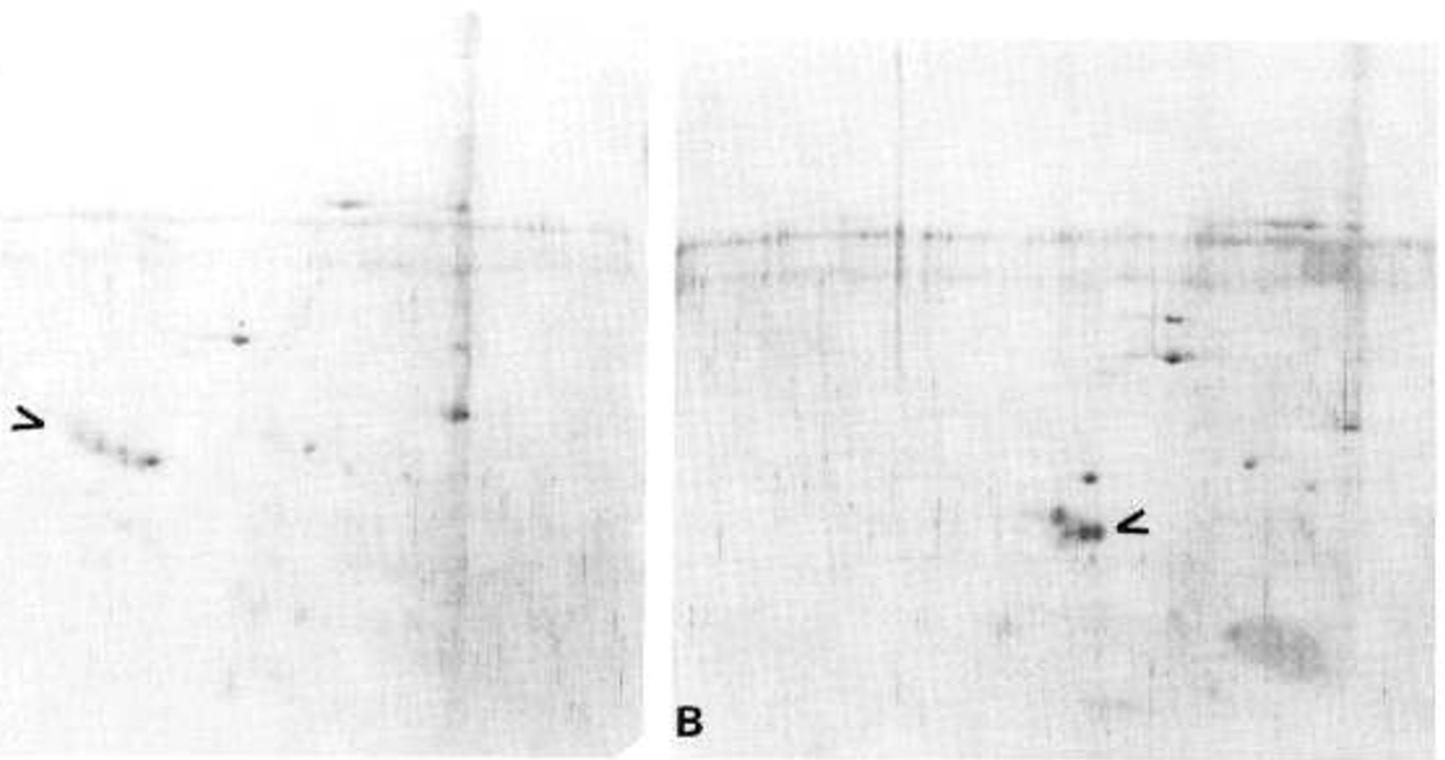

Fig. 3. $A$ and $B$, digestion of glycoproteins $\mathrm{A}_{2}$ with endoglycosidase $\mathrm{F}$. Human surfactant proteins were delipidated, reduced, and aklylated as described in "Methods." Proteins samples (approximately $300 \mu \mathrm{g} / \mathrm{ml}$ ) were suspended resuspended in $50 \mathrm{mM}$ sodium phosphate, pH 6.2 , containing $10 \mathrm{mM}$ EDTA and $0.1 \% \mathrm{NP}-40$. Samples were incubated at $37^{\circ} \mathrm{C}$ in the absence $(A)$ or presence of $2 \mathrm{U} / \mathrm{ml}$ endoglycosidase $\mathrm{F}(B)$. Lyophilized digests were prepared for one- or two-dimensional analysis. Proteins were then stained by silver staining as described in "Methods.".

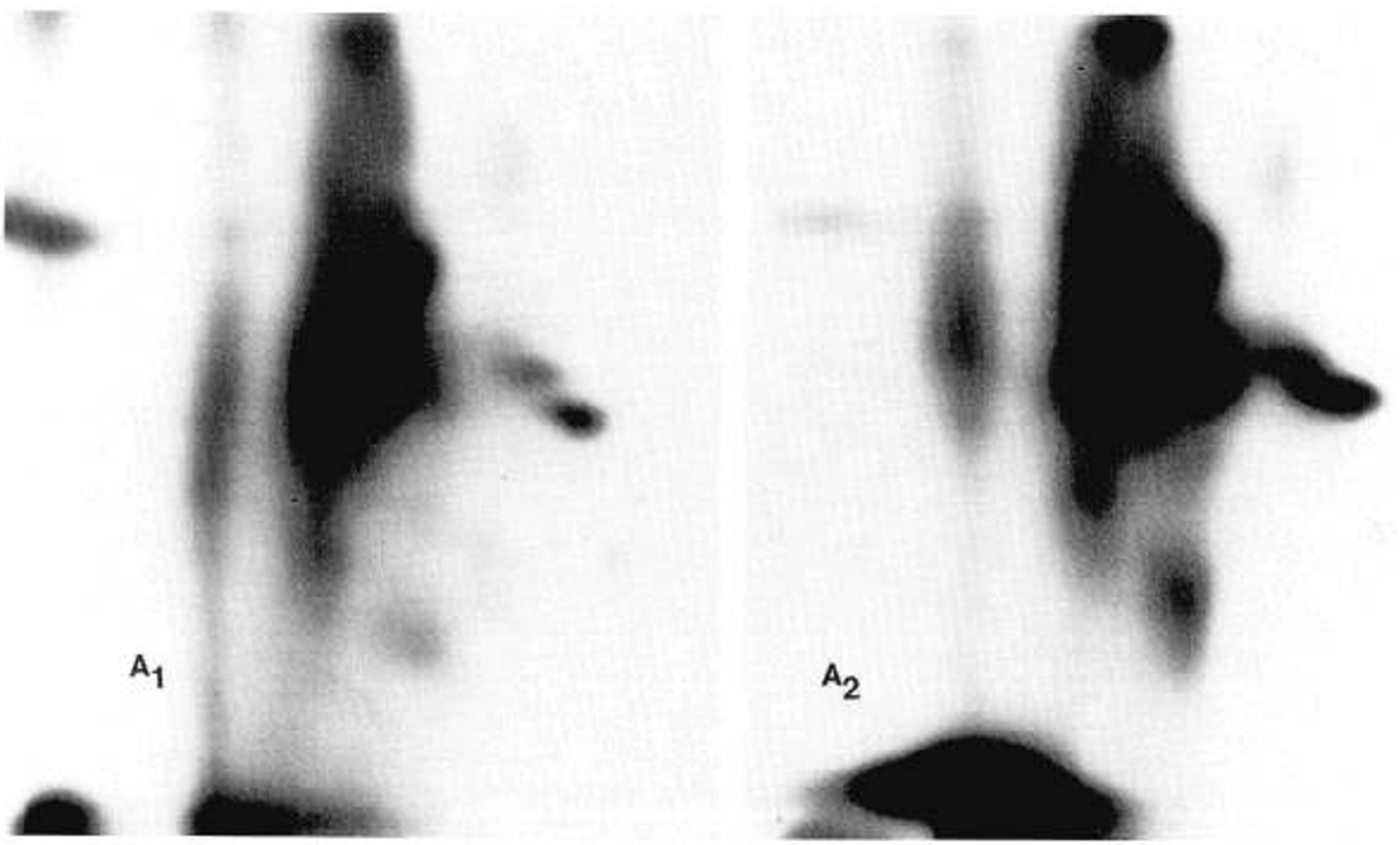

Fig. 4. Chymotryptic-tryptic peptide maps of glycoproteins $A_{1}$ and $A_{2}$ from human surfactant. Single protein spots from $\mathrm{Mr}=34,000$ and 28,000 were excised, iodinated, and subjected to chymotryptic-tryptic peptide analysis as described in "Methods." Samples were then subjected to autoradiography. Peptide maps of glycoproteins $\mathrm{A}_{2}$ and $\mathrm{A}_{2}$ were identical. 
protein was precipitated by addition of cold acetone to $90 \%$ of total volume. The sample was chilled on ice for $10 \mathrm{~min}$ and centrifuged at $20,000 \times g$ for $25 \mathrm{~min}$. The dried protein pellets were then treated essentially as described by Elder and Alexander (25). Reduced and alkylated protein was resuspended in $5 \mathrm{mM}$ sodium phosphate, pH $6.2,10 \mathrm{mM}$ disodium EDTA, $0.1 \% \mathrm{NP}-$ 40 , giving an approximate protein concentration of $300 \mu \mathrm{g} / \mathrm{ml}$. Indicated samples were treated with endoglycosidase $F(2 \mathrm{U} / \mathrm{ml})$ or neuraminidase $(0.1 \mathrm{U} / \mathrm{ml})$ for $16 \mathrm{~h}$ at $37^{\circ} \mathrm{C}$. Samples were also treated as above with bacterial collagenase $(50 \mathrm{U} / \mathrm{ml})$ obtained from Advance Biofactures, Lynbrook, NY, and subjected to IEF-SDS-PAGE. Composition of purified glycoprotein $\mathrm{A}_{2}$ $(34,000)$ was obtained using the Beckman 6300 amino acid analyzer.

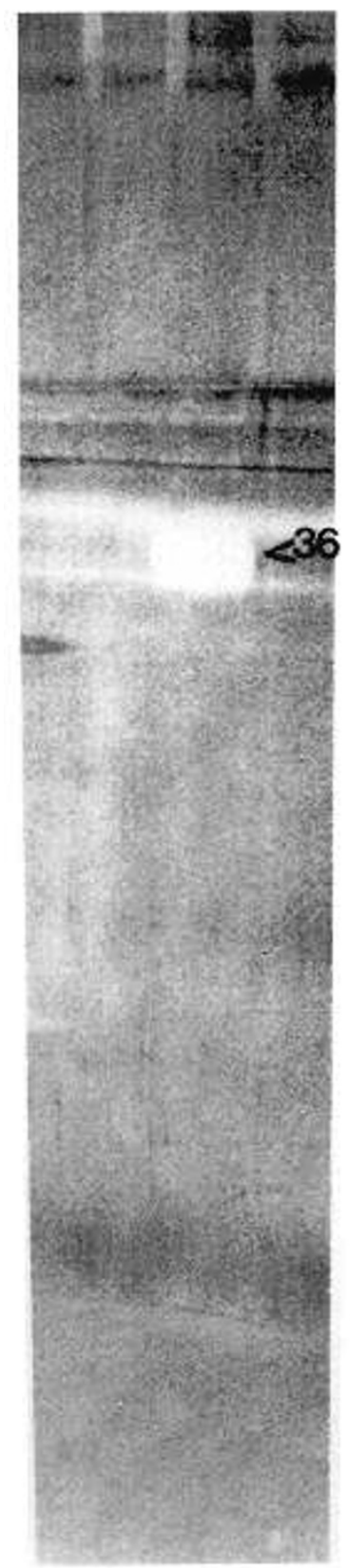

Fig. 5. Purified glycoproteins A after separation by isoelectric focusing and sizing. Human lung lavage surfactant was subjected to preparative isoelectric focusing and sizing as described in "Methods." Purified protein was subjected to SDS-PAGE (13\%). Only glycoprotein A was detectable in the final purified material by one- or two-dimensional SDS-PAGE. Higher molecular weight staining are artifacts related to the silver stain and are observed in empty lanes to each side of the sample.

\section{RESULTS}

Glycoprotein A, $\mathrm{Mr}=34,000, \mathrm{pI} 4.6-5.0$ was the major protein component of surfactant material whether obtained from normal adult lung lavage, human cadaver lung lavage, or amniotic fluid (latter not shown) (Fig. 1 $A$ ). This protein migrated with marked charge and size heterogeneity, pI 4.6-5.0 on isoelectric focusing gels of the reduced material. In the absence of sulfhydryl reduction larger oligomeric forms of the protein were observed with formation of dimers at approximately 65,000-70,000 and larger oligomers, Figure 1B. Immunoblot analysis, using monospecific or antisurfactant antibody identified $\mathrm{Mr}=34,000$ and a immunoreactive protein $\mathrm{Mr}=28,000$, pI 5.0, with silver staining characteristics (salmon-pink staining) similar to that of the larger forms (Fig. 2). We have called these glycoprotein $A_{1}(\mathrm{Mr}=$ $28,000)$ and glycoprotein $\mathrm{A}_{2}(\mathrm{Mr}=34,000)$. Smaller amounts of immunoreactive material were observed $\mathrm{Mr}=50,000,65,000$ 70,000 , and greater in the reduced samples. Treatment of the larger form $(\mathrm{Mr}=34,000)$ with endoglycosidase $\mathrm{F}$ resulted in reduction of most of the material to $\mathrm{Mr}=28,000$. Several more intensely stained protein spots with increased isoelectric points (5.0) were observed (Fig. 3). Charge heterogeneity was decreased and the isoelectric point increased by treatment with neuraminidase supporting the presence of sialic acid in the $\mathrm{Mr}=34,000$ protein, not shown. Reduction of $\mathrm{Mr}=34,000$ to $\mathrm{Mr}=28,000$ by endoglycosidase $\mathrm{F}$ supported the likelihood that these proteins shared a common amino acid sequence. This was confirmed by two-dimensional peptide mapping of tryptic-chymotryptic peptides of the ${ }^{125} \mathrm{I}$-iodoglycoproteins (Fig. $4 A$ and $B$ ). Two-dimensional peptide maps of the proteins $\mathrm{Mr}=34,000$ and 28,000 were indistinguishable from one another. Further analysis of the amino acid composition of the protein required its purification which was accomplished by 2D-IEF-SDS-PAGE and electroelution (18).

Purification of glycoprotein $A_{1}$ and $A_{2}$ was accomplished utilizing a isoelectric focusing followed by separation of proteins by size, taking advantage of the acidic isoelectric point of glycoproteins A (Fig. 5). A variety of purification schemes including DEAE-cellulose, CM-cellulose, and lectin-affinity chromatography were attempted; however, an initial separation by isoelectric focusing provided the best purification and became the method of choice. With the purified human glycoprotein $A_{2}$ (Fig. 5) amino acid composition data were obtained and are listed in Table 1. The protein was found to be rich in glycine and had characteristics similar to that previously described for rat and dog glycoproteins A (11). There are also similarities between the glycoprotein composition presently reported and that of alveolar

Table 1. Partial amino acid composition of human glycoprotein $A^{*}$

\begin{tabular}{cr}
\hline Human glycoprotein $\mathrm{A}_{2}(34,000$ dalton $)$ & 30 \\
ASX & 10 \\
THR & 23 \\
SER & 35 \\
GLX & 12 \\
PRO & 45 \\
GLY & 16 \\
ALA & \\
CYS & 14 \\
VAL & 4 \\
MET & 10 \\
ILE & 20 \\
LEU & 9 \\
TYR & 14 \\
PHE & 4 \\
HIS & 11 \\
LYS & 12 \\
ARG &
\end{tabular}

* Numbers represent the residues detected; CYS was not preserved by this analysis. 
50.

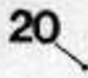

Fig. 6. Coomassie brilliant blue staining of alveolar proteinosis proteins subjected to 2-D-IEF-polyacrylamide gel electrophoresis. Lavage from an alveolar proteinosis patient, approximately $100 \mu \mathrm{g}$, was applied to the 2-D-IEF-polyacrylamide gel electrophoresis as described in "Methods." Approximate molecular weights are indicated $\times 10^{-3}$. The distinct bands utilized for peptide mapping are indicated by the arrows. Larger aggregates are visible in gels but not adequately seen after photography.

glycoprotein $\mathrm{Mr}=36,000$ previously described by Bhattacharyyra and Lynn (14) who previously demonstrated a high glycine content and collagenase-like sequences in the alveolar proteinosis glycoprotein. Because of these similarities in size and composition, comparisons of the protein from human alveolar proteinosis lavage and the glycoprotein A from normal human lavage were made.

Glycoprotein A and the major alveolar proteinosis protein comigrated in 2-D-IEF-SDS-PAGE. Higher molecular weight aggregates were relatively more abundant in the alveolar proteinosis sample (Fig. 6). Similar higher molecular weight forms were detectable by immunoblot analysis of normal lung lavage material (Fig. 2). Bacterial collagenase which is selective for gly $(X, Y)$ gly sequences, selectively reduced human glycoprotein $\mathrm{A}_{2}$ to glycoproteins approximately $\mathrm{Mr}=20,000$ which retained the charge heterogeneity observed in the glycosylated form of the molecule (not shown). The smaller fragment(s) generated by collagenase could not be detected even with high percentage (15\%) one-dimensional SDS-polyacrylamide gels (using silver staining). In order to more fully characterize relationships among the human glycoproteins $\mathrm{A}$ and the human alveolar proteinosis proteins, peptide mapping of the various forms of the alveolar proteinosis proteins was compared with that from glycoproteins $A_{1}$ and $A_{2}$ (Fig. 7). Peptide maps of the major alveolar proteinosis protein $\mathrm{Mr}=34,000$ were identical to those obtained from glycoproteins $A_{1}$ and $A_{2}$ from normal human lavage. The larger molecular weight forms of the proteinosis samples, $\mathrm{Mr}=50,000$, $68,000-70,000,100,000$, and greater were also identical to the peptide maps of glycoproteins $A_{1}$ and $A_{2}$. No new peptides were identified in any of the larger molecular weight proteins, suggesting that they result from aggregation of the 34,000 or 28,000 dalton precursors or their fragments. Smaller immunoreactive proteins were also observed in alveolar proteinosis samples, $\mathrm{Mr}$ $=20,000$, pI 4.8. Peptide maps of this smaller protein were similar to those of glycoproteins $A_{1}$ and $A_{2}$; however, they lacked several major tryptic peptide fragments. The absence of any new proteolytic fragments generated from the higher molecular weight forms of alveolar proteinosis protein strongly supports their identity as aggregates of either the 34,000 and 28,000 precursors or their fragments.

\section{DISCUSSION}

The present study partially characterizes glycoproteins A from surfactant from human lung lavage, amniotic fluid, and alveolar proteinosis material. Human surfactant associated glycoprotein $\mathrm{A}_{2}, \mathrm{Mr}=34,000$ after sulfhydryl reduction was detected in all of these preparations and appears to be formed by N-linked glycosylation of proteins $\mathrm{Mr}=28,000$. The proteins were present as sulfhydryl-dependent oligomers composed of glycoproteins A in the absence of sulfhydryl reduction. Higher molecular weight aggregates and proteolytic fragments of glycoproteins A account for the various forms present in alveolar proteinosis material. Human glycoproteins $\mathrm{A}$ are rich in glycine and contain a significant portion of collagen-like amino acid sequence which is also required for the observed sulfhydryl-dependent oligomerization.

Glycoproteins A were identified as major protein components of surfactant and alveolar proteinosis samples; the proteins were virtually identical from these sources as assessed by 2-D-IEFPAGE and peptide mapping. Reduction of glycoprotein $\mathrm{A}_{2} \mathrm{Mr}$ $=34,000$ to $A_{1}(\mathrm{Mr}=28,000)$ by endoglycosidase $F$, shared immunoreactivity and the observation that tryptic peptide maps of these proteins were identical, strongly supports the concept that glycoprotein $A_{2}$ is a glycosylated form of the polypeptide 


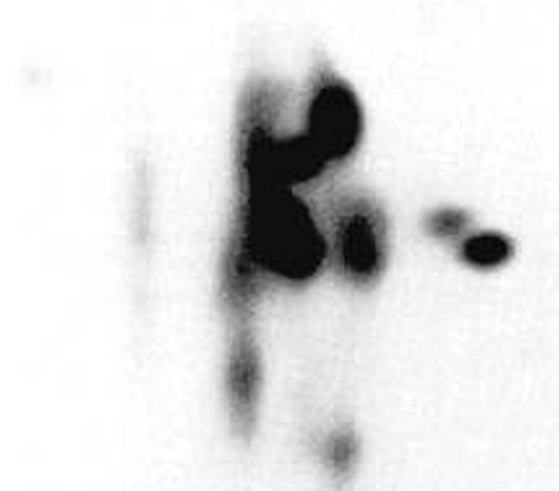

A

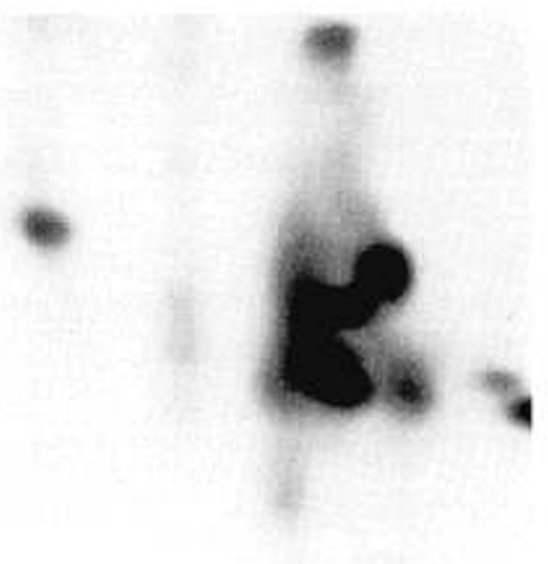

C

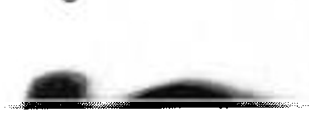

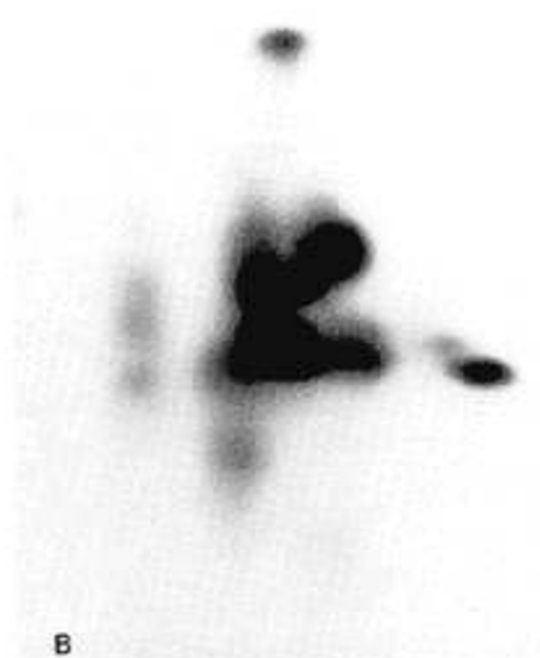

B

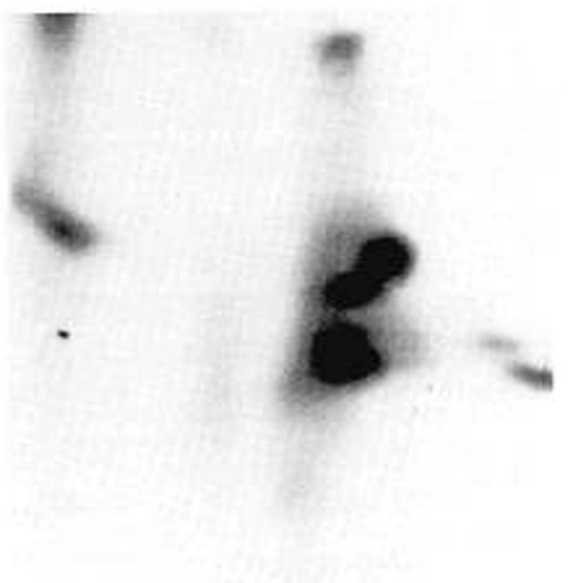

D

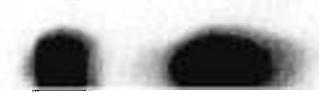

Fig. 7. Chymotryptic-tryptic peptide maps of alveolar proteinosis proteins. Proteins as indicated from Figure 6 were excised, iodinated, and subjected to chymotryptic-tryptic mapping analysis as described in "Methods." lodinated peptides were then subjected to autoradiography for approximately $24 \mathrm{~h}$. Peptide maps of the proteins were identical to those seen in Figure 4 from normal lung lavage glycoproteins A. $A$, peptide map of $\mathrm{Mr}=36,000 ; B, 65,000-70,000 ; C, \mathrm{Mr}=50,000 ; D, \mathrm{Mr}=20,000$. Larger forms, $\mathrm{Mr}=100,000$ and greater were also identical (not shown).

precursor $\mathrm{Mr}=28,000$. Endoglycosidase $\mathrm{F}$, specific for $\mathrm{N}$-linked, mannose-containing complex-oligosaccharides, decreased molecular weight and increased the isoelectric point of $\mathrm{Mr}=34,000$ to 28,000 . In agreement with other studies with rat and rabbit glycoprotein $\mathrm{A}$, treatment with neuraminidase reduced the charge heterogeneity and increased the isoelectric point of $\mathrm{Mr}=$ 34,000 supporting the presence of sialic acid which is commonly associated with such complex oligosaccharides $(12,29)$. The oligosaccharide components presently observed are consistent with the recent data by Bhattacharyya et al. (15) who demonstrated N-linked mannose-rich oligosaccharides in proteins $\mathrm{Mr}$ $=36,000$ from alveolar proteinosis samples.

The characteristics of migration of human glycoproteins $A$ are similar to those previously described for this protein from the dog, rabbit, human, and rat $(11-13,16,30)$. Peptide maps of the human glycoprotein A were also similar to but not identical to those obtained by our laboratory from rat and canine glycoprotein A (13; unpublished observations). Characteristics and compositions are also similar to those reported for glycoprotein $\mathrm{A}$ in the dog and rat $(11,12)$. The partial amino acid composition data presently reported are quite similar, but distinct from that reported by Bhattacharyya and Lynn (15) for the alveolar proteinosis glycoprotein, $\mathrm{Mr}=36,000$. Our present amino acid composition data, demonstrating high glycine content and the observation that a highly purified bacterial collagenase selectively reduced glycoprotein $\mathrm{A}_{2}$ to peptides of $\mathrm{Mr}=20,000-23,000$ are consistent with the presence of a significant collagen-like amino acid sequence(s) in the molecule. Charge heterogeneity of the collagenase-resistant region suggests that much if not all of the glycosylation and sialic acid is present in a noncollagenous region of the molecule. The collagenase-resistant glycoprotein fragments no longer formed sulfhydryl-dependent aggregates suggesting that the collagen-like domain is required for the sulfhydryl-dependent oligomerization of the molecule. On the basis of composition and sequence information, Bhattacharyya and Lynn (15) suggested that the glycoprotein $\mathrm{Mr}=36,000$ was a fragment of larger glycoproteins $\mathrm{Mr}=80,000$ and 62,000 present in the alveolar proteinosis. In the present study, a number of larger proteins were readily identifiable as major components of the alveolar proteinosis material. However, peptide mapping of the 
acidic proteins supports their origin as aggregates of glycoproteins $A_{1}$ and $A_{2}$ or their fragments. Larger molecular weight proteins contain no peptides which were not identifiable as major peptides in glycoprotein $A_{1}$ or $A_{2}$. Smaller forms of the molecules contained most but not all of the characteristic tryptic peptides seen in glycoprotein $A_{1}$ and $A_{2}$ suggesting their origin results from proteolysis of glycoproteins $A$.

The concept that glycoprotein $\mathrm{A}_{1}(\mathrm{Mr}=28,000)$ is a precursor polypeptide to the other forms is further supported by recent studies of glycoprotein $A_{1}$ and $A_{2}$ synthesized by rat type II epithelial cells by this laboratory (13). Pulse-chase experiments performed with ${ }^{35} \mathrm{~S}$-methionine labeled type II epithelial cells in primary culture, resulted in immunoprecipitable proteins $\mathrm{Mr}=$ 26,000 which was observed early during labeling and proceeded to form the larger forms of glycoproteins $A$ with continued incubation. Rat glycoprotein $A_{1}$ comigrated with this early immunoprecipitable form and comigrated with the primary translation product of rat poly $\mathrm{A}^{+} \mathrm{mRNA}$ immunoprecipitated with the antiglycoprotein A antisera (30). These rat studies and the present work with human surfactant strongly support the identity of glycoprotein $A_{1}$ as the precursor for the various glycosylated and oligomeric forms of glycoproteins $A$ identified in normal surfactant as well as those present in greater abundance in alveolar proteinosis proteins.

Purification of the human glycoproteins $A_{1}$ and $A_{2}$ has been accomplished by isoelectric focusing, molecular sizing, and electroelution utilizing the acidic isoelectric point of the molecules as a major purification step. The present procedure is fast and can readily be adapted to a preparative level under nondenaturing conditions. Such purification procedure therefore will likely make readily available significant quantities of undenatured glycoproteins $\mathrm{A}$ for further analysis of its structure and function.

Surfactant contains a variety of serum and nonserum proteins which may contribute to surfactant function. Glycoproteins A are a major surfactant specific protein and is synthesized by the type II epithelial cell lining the alveolar lining of the lung. Glycoproteins A are clearly developmentally regulated appearing only in late gestation in amniotic fluid and lung tissues (31). The physiological function of surfactant-associated glycoproteins A and the importance of its remarkable developmental expression by the respiratory epithelium remain to be more fully clarified.

Acknowledgments. The authors thank Robert Johnson, Ph.D. and Eldridge Baker, M.D. for obtaining amniotic fluid samples. Selected bronchial lavage was kindly supplied by Dr. Robert Baughman. Alveolar proteinosis sample was the kind gift of Dr. William Taeush.

\section{REFERENCES}

1. King RJ 1982 Pulmonary surfactant. J Appl Physiol 53:1-8

2. King RJ, MacBeth MC 1979 Physiochemical properties of dipalmitoyl phosphatidylcholine after interaction with an apolipoprotein of pulmonary surfactant. Biochim Biophys Acta 557:86-101

3. Metcalfe IL, Enhorning G, Possmayer F 1980 Pulmonary surfactant-associated proteins: their role in the expression of surface activity. J Appl Physiol 49:3441

4. Notter RH, Finkelstein JN, Taubold RD 1983 Comparative adsorption of natural lung surfactant, extracted phospholipids, and artificial phospholipid mixtures to the air-water interface. Chem Phys Lipids 33:67-80
5. Egan EA, Notter RH, Kwong MS, Shapiro DL 1983 Natural and artificial lung surfactant replacement therapy in premature lambs. J Appl Physiol 55:875883

6. Fujiwara T, Chida S, Watabe Y, Maeta M, Morita T, Abe T 1980 Artificial surfactant therapy in hyaline-membrane disease. Lancet 1:55-59

7. Hallman M, Merritt TA, Schneider H, Epstein BL, Mannino F, Edwards DK, Gluck L 1983 Isolation of a human surfactant from amniotic fluid and a pilot study of its efficacy in respiratory distress syndrome. Pediatrics $71: 473$ 482

8. Smyth JA, Metcalf JL, Duffy P, Possmeyer F, Bryan MH, Enhorning O 1983 Hyaline membrane disease treated with bovine surfactant. Pediatrics 71:913917

9. Halliday RL, Reid M, Meban C, McClure G, Lappini TRJ, Thomas PS 1984 Controlled trial of artificial surfactant to prevent respiratory distress syndrome. Lancet 1:476-478

10. King RJ, Clements JA 1972 Surface active materials from dog lung. II. Composition and physiological correlations. Am J Physiol 223:715-726

11. Sueishi K, Benson BJ 1981 Isolation of a major apolipoprotein of canine and murine pulmonary surfactant biochemical and immunochemical characteristics. Biochim Biophys Acta 665:442-453

12. Katyal SL, Singh G 1984 Analysis of pulmonary surfactant apoproteins by isoelectric focusing. Biochim Biophys Acta 794:411-418

13. Weaver TE, Hull WM, Ross GF, Whitsett JA 1984 Intracellular and oligomeric forms of surfactant associated apolipoproteins $\mathrm{A}$ in the rat. Biochim Biophys Acta 827:260-268

14. Bhattacharyya SN, Lynn WS 1979 Structural characterization of a glycoprotein isolated from alveoli of patients with alveolar proteinosis. $\mathrm{J}$ Biol Chem 254:5191-5198

15. Bhattacharyya SH, Lynn WS, Dabrowski J, Trauner K, Hull WE 1984 Structure elucidation by one- and two-dimensional $360-$ and $500-\mathrm{MHz}^{1} \mathrm{H}$ NMR of the oligosaccharide units of two glycoproteins isolated from alveoli of patients with alveolar proteinosis. Arch Biochem Biophys 231:72-85

16. Phelps DS, Taesch HW, Benson B, Hawgood S 1984 Electrophoretic and immunochemical characterization of surfactant associated proteins. Biochim Biophys Acta 791:226-238

17. Shelly SA, Balis JU, Paciga JE, Espinoza CG, Richman AV 1982 Biochemical composition of adult human lung surfactant. Lung 160:195-206

18. Hunkapiller MW, Lujan E, Ostrander F, Hood LE 1983 Isolation of microgram quantities of proteins from polyacrylamide gels for amino acid sequence analysis. Meth Enzymol 91:227-236

19. Laemmli U 1970 Cleavage of structural proteins during assembly of the head of bacteriophage $\mathrm{T}_{4}$. Nature 227:680-686

20. Anderson L, Anderson NG 1977 High resolution two-dimensional electrophoresis of human plasma proteins. Proc Natl Acad Sci USA 74:5421-5424

21. Garrison J, Johnson ML 1982 A simplified method for computer analysis of autoradiograms from two-dimensional gels. J Biol Chem 257:13144-13149

22. Towbin H, Staehelin T, Gordon J 1979 Electrophoretic transfer of proteins from polyacrylamide gels to nitrocellulose sheets. Proc Natl Acad Sci USA $76: 4350-4354$

23. Saravis CA 1984 Improved blocking of nonspecific antibody binding sites on nitrocellulose membranes. Electrophoresis 5:54-55

24. Sammons D, Adams LD, Nishizawa EE 1981 Ultrasensitive silver based color staining of polypeptides in polyacrylamide gels. Electrophoresis $2: 135-141$

25. Elder JH, Alexander S 1982 Endo-B-N-acetyl glucosaminidase F: endoglycosidase from flavobacterium mening osepticum that cleaves both high mannose and complex glycoproteins. Proc Natl Acad Sci USA 79:4540-4544

26. Greenwood FC, Hunter WM, Glover JS 1963 The preparation of ${ }^{131} \mathrm{I}$-labelled human growth hormone of high specific activity. Biochem J 89:114-123

27. Gibson W 1974 Polyoma virus proteins: a description of the structural proteins of the virion based on polyacryalmide gel electrophoresis and peptide analysis. Virology 62:319-336

28. Folch J, Lees M, Sloane-Stanley GH 1957 A simple method for the isolation and purification of total lipids from animal tissue. J Biol Ehcm 226:497509

29. Ng VL, Herndon VL, Mendelson CR, Snyder JM 1983 Characterization of rabbit surfactant associated proteins. Biochim Biophys Acta 754:218-226

30. Whitsett JA, Ross G, Hull W, Weaver T 1984 Synthesis of surfactant associated apolipoprotein A by rat Type II epithelial cells: primary translation products and post-translational modification. Biochim Biophys Acta (in press)

31. Katyal SL, Singh G 1983 An enzyme linked immunoassay of surfactant apoproteins. Its application to study of fetal lung development in the rat. Pediatr Res 17:439-443 